\title{
PENGEMBANGAN APLIKASI PENJUALAN BARANG BERBASIS WEBSITE UNTUK MEDIA PRAKTIK JURUSAN PEMASARAN
}

\author{
Teguh Suripno, Tri Widodo \\ Universitas Teknologi Yogyakarta, Yogyakarta 55111 \\ SMK Muhammadiyah Cangkringan, Yogyakarta 5511 \\ teguhsuripno16@gmail.com, triwidodo@uty.ac.id
}

\begin{abstract}
ABSTRAK
SMK Muhammadiyah Cangkringan merupakan sekolah menengah kejuruan swasta yang berada di Timur Laut dari ibukota Kabupaten Sleman Daerah Istimewa Yogyakarta. SMK Muhammadiyah Cangkringan memiliki sistem informasi yaitu sistem informasi penjualan barang yang terbatas pada offline. Tujuan penelitian ini adalah mengembangan aplikasi penjualan barang berbasis website. Aplikasi penjualan barang ini dibuat mengunakan CSS Framework Bootstrap dan Framework Codeigniter, serta dengan bahasa pemrograman PHP dan database MYSQL.
\end{abstract}

Kata kunci: Aplikasi Penjualan, Sistem Informasi, SMK

\begin{abstract}
Muhammadiyah Cangkringan Vocational School is a private vocational high school located in the Northeast of the capital city of Sleman, Yogyakarta. SMK Muhammadiyah Cangkringan is an information system for selling goods that can support teaching and learning in the marketing department, but has limitations because the system that runs is an offline sales system. The purpose of this research is to develop a website-based goods sales application in the marketing department. This item sales application is created using CSS Bootstrap Framework and Codeigniter Framework, as well as with the PHP programming language and MYSQL database.
\end{abstract}

Keywords: Sales Application, Information System, SMK

\section{PENDAHULUAN}

SMK Muhammadiyah Cangkringan pertama bernama SMEA (Sekolah Menengah Ekonomi Atas) Muhammadiyah Cangkringan. Didirikan oleh Pimpinan Muhammadiyah Cabang Cangkringan pada tanggal 4 Februari 1967, dengan alamat Kliwang Argomulyo Cangkringan Sleman Yogyakarta. SMK Muhammadiyah Cangkringan berada di Timur Laut dari ibukota Kabupaten Sleman. SMK Muhammadiyah Cangkringan memiliki 5 penjurusan antara lain: Akuntansi, Pemasaran, Teknik Kendaraan Ringan (Mobil), Teknik Sepeda Motor dan Busana Butik.

Seiring perkembangan zaman pada saat ini dengan pesatnya kemajuan teknologi, komputer sudah menjadi kebutuhan sehari-hari terutama pada sekolah, agar kegiatan dapat lebih efektif dan efisien. Salah satu kemudahan yang dijanjikan oleh teknologi berbasis komputer di zaman sekarang ialah adanya sistem informasi penjualan barang berbasis website disekolah-sekolah guna menunjang proses pembelajaran pada jurusan pemasaran. Namun beberapa sekolah umumnya belum mengunakan sarana penunjang seperti itu. Hal ini jelas kurang membekali kemampuan siswa dalam menggunakan sistem, terutama sistem penjualan karena mengingat era saat ini penggunaan sistem sangat dibutuhkan. SMK Muhammadiyah Cangkringan khususnya di jurusan pemasaran memiliki sistem informasi penjualan barang yang 
digunakan sebagai media praktik, namu terbatas pada penjualan offline.

Oleh karena itu penulis tertarik untuk mengembangkan suatu sistem yang dapat membuat proses pembelajaran menjadi lebih menarik, agar para siswa memiliki bekal kemampuan lebih dengan cara dikembangkannya aplikasi penjualan barang berbasis website.

Sandi, K. (2014) melakukan penelitian tentang pembuatan sistem informasi berbasis web untuk memperluas pangsa pasar. Tujuan penelitian menitikberatkan menghasilkan sistem informasi penjualan berbasis web sebagai sarana untuk memperluas pangsa pasar melalui transformasi proses bisnis kearah digitisasi, mobilitas modal dan liberalisasi produk dan jasa. Metode analisis perluasan pasar menggunakan analisis kesempatan pasar, dan menggunakan perancangan model bisnis, antarmuka pelanggan, komunikasi pasar dan rancangan implementasi. Perancangan aplikasi pada penelitian ini menggunakan model incremental development dengan pendekatan berorientasi objek. Sistem aplikasi ini dikembangkan dengan menggunakan sejumlah aplikasi, yaitu Dreamweaver CS8, PHP, CSS, dan jQuery. Hasil dari penelitian ini ialah sistem informasi penjualan berbasis website.

Yessy, F. dan Suprianto melakukan penelitian tentang sistem informasi penjualan produk krupuk berbasis web responsive. Dalam membangun sistem informasi ini penelitian menggunakan metode web responsive dengan menggunakan Bahasa pemrograman PHP serta MySQL untuk databasenya. Penelitian ini menghasilkan sistem informasi penjualan yang efektif yaitu yang dikelola penuh oleh seorang administrator dalam mengendalikan semua informasi yang berkaitan dengan tata kelola data produk dan data penjualannya, serta diberikan fasilitas menu khusus bagi customer untuk memperoleh informasi dan dapat melakukan transaksi. Kesimpulan yang diperoleh pada penelitian ini yaitu sistem mampu meningkatkan tata kelola data produk dan penjualan yang efektif.

Mikhael, F. dan Heri, K. (2017) melakukan penelitian tentang sistem informasi penjualan berbasis web pada PT Era Makmur Cahaya Damai Bekasi. Tujuan penelitian yang dilakukan untuk membuat PT. Era Makmur Cahaya Damai lebih efisien dalam konteks penjualan yang mudah dengan menggunakan web. Metode yang digunakan disini lebih mengarah kepada proses penelitian dengan Metode Waterfall. Dalam dibangunnya sistem seperti ini, supaya lebih memudahkan dalam penjualan, melakukan transaksi dengan mudah, memudahkan pembeli dalam pembelian barang secara online jika jauh, meningkatkan pendapatan dan memperluas promosi penjualan pada PT. Era Makmur Cahaya Damai. Sistem informasi ini dikembangkan menggunakan Bahasa pemrograman PHP serta MySQL untuk databasenya. Hasil dari penelitian ini ialah sistem informasi penjualan berbasis website.

Secara umum dari beberapa penelitian di atas memiliki kelemahan dan kelebiah, yaitu kelemahan sistem yang dikembangkan pada bebera penelitian diatas ialah sistem dikelola oleh satu orang admin sehingga dapat memperlambat proses pendataan, sementara kelebihan pada sistem yang dikembangkan pada bebera penelitian diatas ialah konsumen dapat memesan produk secara langsung melalui website sehingga dapat memperluas pangsa pasar, namun pada penelitian yang dilakukan oleh Yessy, F. dan Suprianto. (2015) hanya memiliki fitur untuk mengelola data penjualan dan pembelian. Sedangakan keunggulan sistem pada yang akan dikembangkan pada rencana penelitian ini ialah memiliki dua hak akses yaitu admin dan pelanggan. Pada sistem yang akan dikembangkan ini juga memiliki 
beberapa fitur pendukung lainnya yang bisa menjadi keunggulan dari sistem ini yaitu sistem talah didukung dengan pengelolaan laba dan pada sistem ini juga didukung dengan kemampuan perhitungan ongkos kirim dengan menggunakan API Raja Ongkir. Dengan dukungan API Raja Ongkir ini sistem dapat dengan mudah menentukan besarnya ongkos kirim yang harus dibayar oleh pembeli.

\section{METODOLOGI PENELITIAN}

Metode penelitian yang digunakan dalam perancangan dan pembuatan program ini adalah sebagai berikut:

Pembuatan sistem informasi penjualan barang ini mengunakan struktur pemodelan waterfall dengan beberapa tahapan aktivitas yang terstruktur dan terarah dimana pada setiap tahapan akan dicapai hasil yang maksimal guna menghasilkan aplikasi yang baik. Adapun tahapan yang dilakuakan antara lain analisis dan definisi kebutuhan sistem, desain sistem, serta implementasi sistem.

Adapun langkah-langkah dalam metode waterfall dalam penelitian ini adalah sebagai berikut:

a. Analysis

Analysis kebutuhan sistem dan software adalah proses menentukan arsitektur sistem secara total dan menentukan ukuran data dan jumlah data. Pada tahap ini merupakan tahap penyempurnaan dari sistem engineering, dimana pada tahap ini mulai ditentukannya bagaimana kerangka arsitektur program, seberapa besar ukuran dan jumlah data.

Tahap ini dilakuakan agar data-data pendukung yang dibutuhkan dalam membangun sistem dapat diketahui. Data-data pendukung yang dimaksud diperoleh dari hasil observasi dan wawancara dari hasil ini diperoleh masalah yaitu belum tersedianya sistem informasi penjualan barang.

b. Design

Design adalah proses menentukan dasar-dasar pembentukan dan pemilihan struktur data, strukrtur program, arsitektur program, pemilihan algoritma, intereksi dengan user. Pada tahap ini mulai ditentukan bagaimana gambaran program yang akan dikembangkan.

Pada tahap ini dilakukan melalui beberapa tahapan, berikut adalah tahapan-tahapan yang dilakukan, yaitu sebagai berikut:

1) Diagram arus data (DAD)

Diagram arus data merupakan sebuah diagram yang digunakan untuk menjelaskan alur data dari sebuah sistem, yang digunakna dengan tujuan untuk memahami sistem secara terstruktur dan jelas.

2) Desain database dan ERD (Entity Relationship Diagram)

Desain database disini merupakan sebuah sekema database yang akan diterapkan pada sebuah sistem, desain database di penelitian ini meliputi data alat bengkel, data transaksi yaitu berupa data peminjaman barang dan pengembalian barang, seta data pelaporan dari kedua transaksi tersebut yang di kemas dalam bentuk laporan perbulan. Sedangkan ERD merupakan sebuah sekema database yang saling terhubung.

3) Desain user interface

Desain user interface merupakan tahap pembuatan tampilan antarmuka pada sebuah sistem. 
c. Coding

Coding adalah proses implementasi desain ke dalam baris-baris program, pemilihan bahasa. Pada tahap ini pentransformasian desain ke dalam program dilakukan dengan menggunakan bahasa pemrograman PHP dan MySQL.

\section{d. Testing}

Testing merupakan pengujian kebenaran program, error debugging. Tahap ini dilakukan menggunakan Black-Box testing, dimana pengujian dilakikan menggunakan dua tahap, yaitu penggujian internal dan eksternal. Pada tahap ini bisa dilihat pada bagian pengujian sistem.

\section{e. Maintanance}

Maintanance merupakan proses perawatan software agar dapat digunakan seterusnya. Tahap ini dilakukan pemeliharaan program agar dapat digunakan dengan baik, perawatan yang dilakukan pada tahap ini ialah memastikan program telah berjalan dengan normal setelah dilakukukan proses instalasi.

Model Waterfall banyak mengandung iterasi sehingga membuat sulit bagi pihak manajemen untuk memeriksa seluruh rencana dan laporan. Maka dari itu, setelah sedikit iterasi, biasanya bagian yang telah dikembangkan akan dihentikan dan dilanjutkan dengan langkah pengembangan selanjutnya. Dari langkah-langkah pengembangan sistem waterfall, penelitian ini menerapkan langkah analysis, desain, coding, testing dan maintanance. Testing / pengujian dalam penelitian ini menggunakan Black-Box Testing.

\section{HASIL DAN PEMBAHASAN}

\section{Implementasi Sistem}

Dalam usaha membangun aplikasi penjulan barang berbasis website ini dibutuhkan sebuah bahasa pemrograman yaitu bahasa pemrograman PHP dan database MySql. Melalaui bahasa pemrograman ini diharapkan bisa diwujudkan sebuah program berbasis website.

Perwujudan program dari aplikasi yang telah dibuat ini adalah sebuah aplikasi penjualan barang berbasis website. Program ini menggunakan menu utama sesuai dengan prosedur-prosedur masukan dalam perancangan sistem, sehingga alur-alur program akan mengikuti alur jalannya data pada gambaran diagram sistem.

\section{Pembahasan Sistem}

Implementasi sistem adalah tahap lanjutan dari tahap perancangan sistem. Melalui tahap ini akan diketahui bagaimana cara memulai, menjalankan dan mengakhiri program yang telah dibuat. Implementasi sistem ini menjelaskan bahwa implementasi yang dibuat adalah aplikasi penjualan barang.

Pada bagian implementasi sistem ini akan dijelaskan mengenai penggunaan dari aplikasi penjualan barang, penjelasan aplikasi penjualan barang, dan aplikasi yang dibuat berupa tampilan user atau pengguna dan tampilan admin.

\section{Halaman User}

Halaman user merupakan halaman yang nantinya akan digunakan untuk bertransaksi seorang user / pembeli. Berikut beberapa tampilan halaman user:

\section{a. Halaman Home}

Halaman home merupakan halaman awal yang dapat diakses oleh user, baik sebelum ataupun sesudah login. Berikut tampilan dari halaman home: 


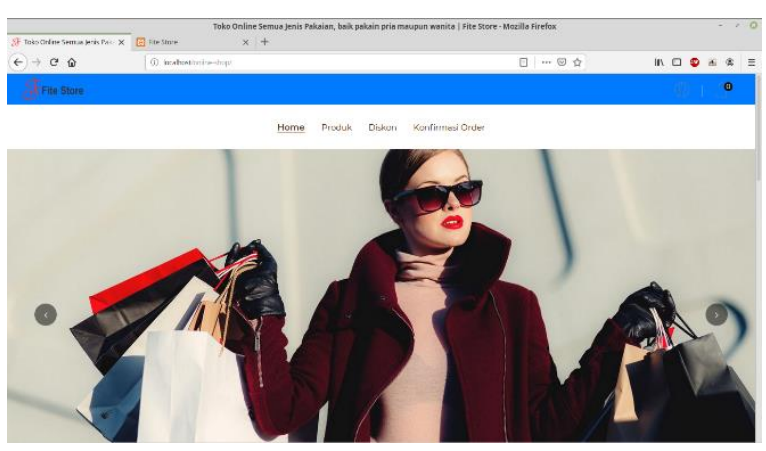

Gambar 4. 1 Halaman Home

b. Halaman Login dan Registrasi

Halaman login dan registrasi merupakan sebuah halaman yang digunakan user untuk melakukan aktivitas login maupun registrasi akun. Berikut tampilan halaman login dan registrasi:

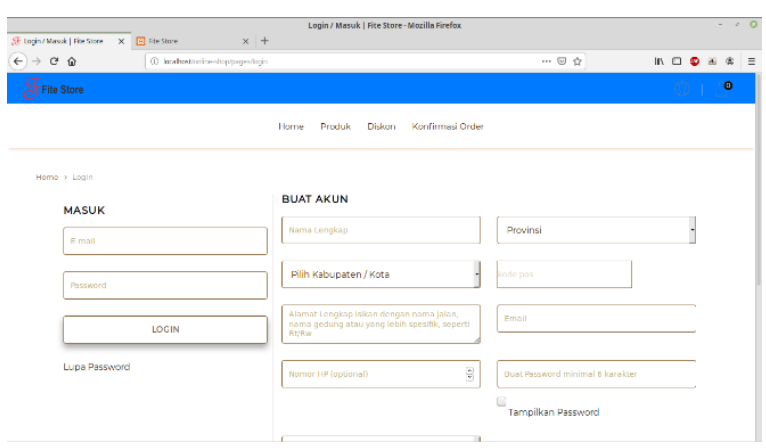

Gambar 4. 2 Halaman Login \& Registrasi

c. Halaman Produk

Halaman produk ini merupakan sebuah halaman yang digunakan untuk melihat data produk. Pada halaman ini user juga bisa melakukan aktivitas membeli produk yang ada. Berikut tampilan dari halaman produk:

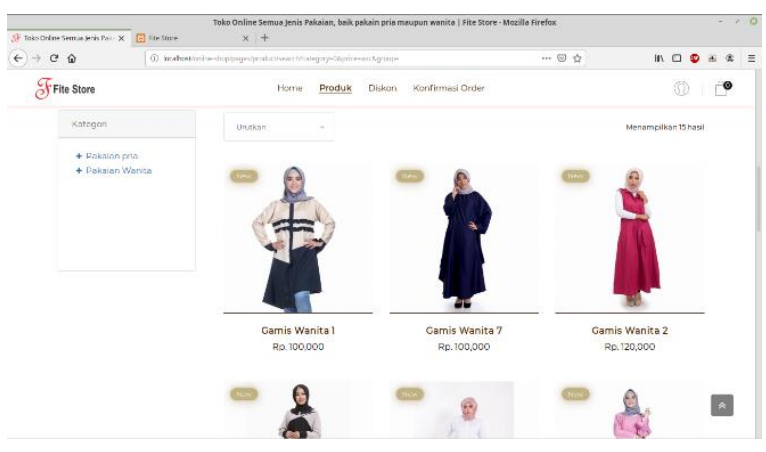

Gambar 4. 3 Halaman Produk

\section{d. Halaman Cart}

Halaman cart merupakan sebuah halaman yang digunakan user untuk melihat detail produk yang nantinya akan dimasukan ke keranjang belanja guna melakukan pembelian. Pada halaman ini user bisa memilih jumlah produk yang akan dibeli namun menyesuaikan stok produk yang ada, di halaman ini user juga bisa memberikan catatan pada penjual contoh memberikan catatan ukuran produk yang akan dibeli. Berikut tampilan halaman cart:

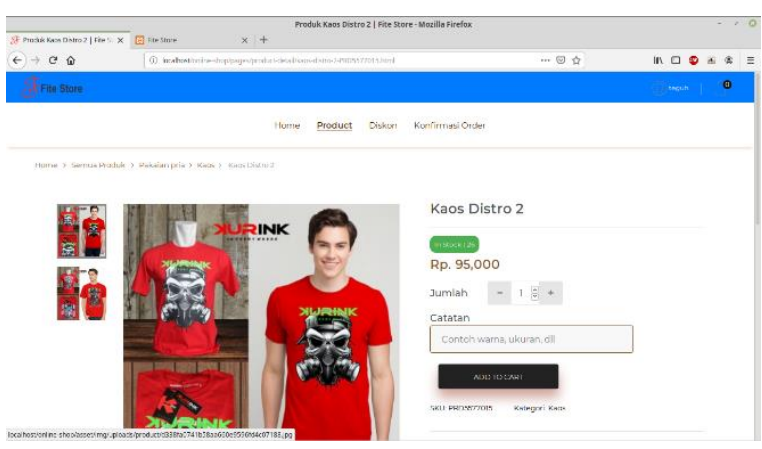

Gambar 4. 4 Halaman Cart

\section{e. Form Pembeli}

Halaman ini merupakan sebuah halaman yang digunakan untuk proses awal transaksi, yaitu memasukkan data penerima barang, yang mana data penerima diambil dari data base user. Berikut tampilan halaman form pembeli:

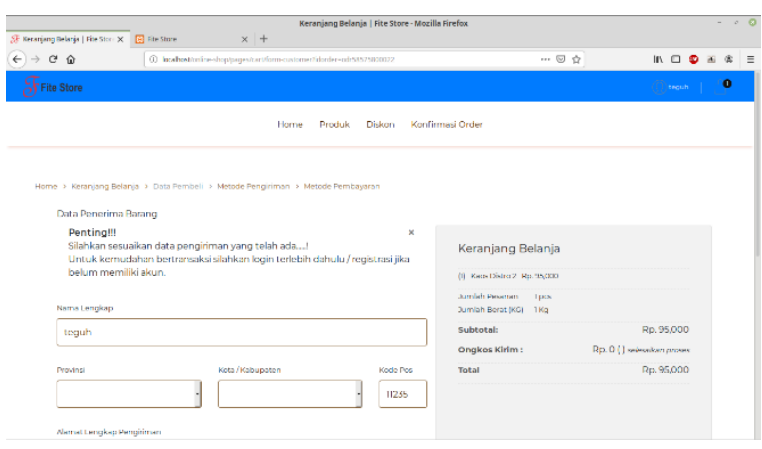

Gambar 4. 5 Form Pembeli

\section{Halaman Admin}

Halaman admin merupakan halaman yang nantinya akan digunakan untuk oleh admin. Berikut beberapa tampilan halaman admin: 
a. Halaman Login Admin

Halaman ini merupakan halaman yang digunakan admin untuk melakukan login agar nantinya dapat mengakses halaman admin. Beikut tampilan halaman login admin:

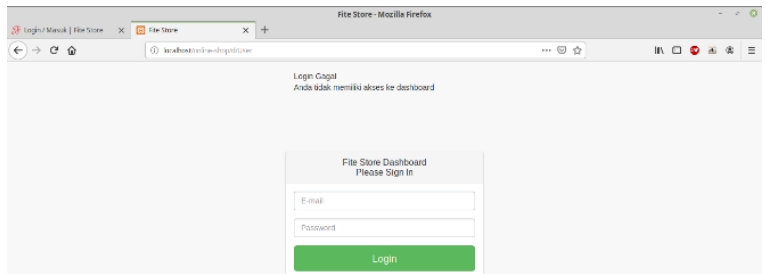

Gambar 4. 6 Halaman Login Admin

b. Halaman Dashboard Admin

Halaman ini merupakan halaman awal pada halaman admin. Berikut tampilan halaman dashboard admin:

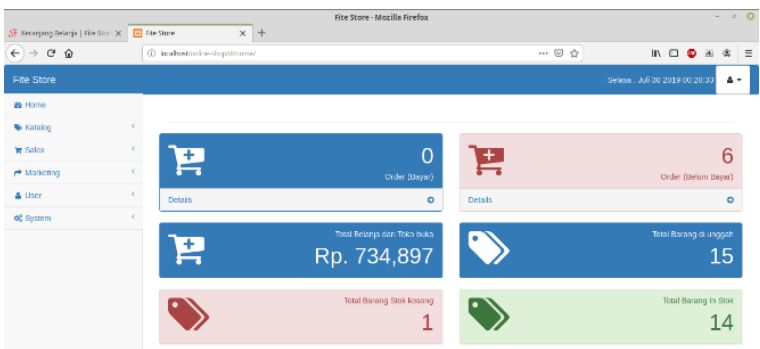

Gambar 4. 7 Halaman Dashboard Admin

c. Halaman Data Kategori

Halaman ini digunakan untuk menampilkan data kategori. Berikut tampilan halaman data kategori:

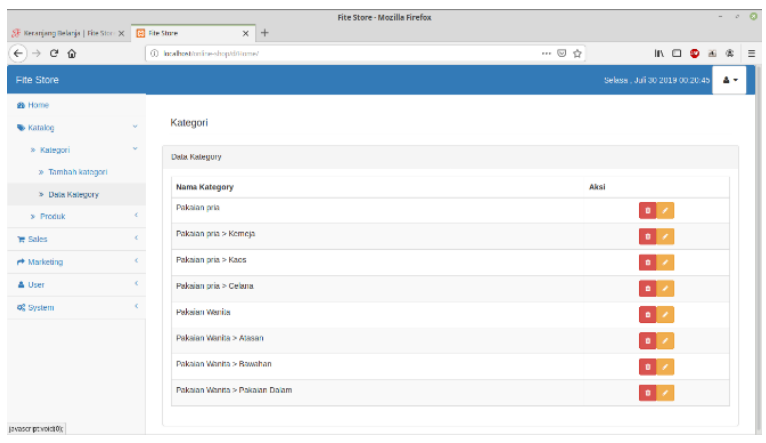

Gambar 4. 8 Halaman Data Kategori d. Halaman Data Produk

Halaman ini digunakan untuk menampilakan data produk. Berikut tampilan halaman data produk:

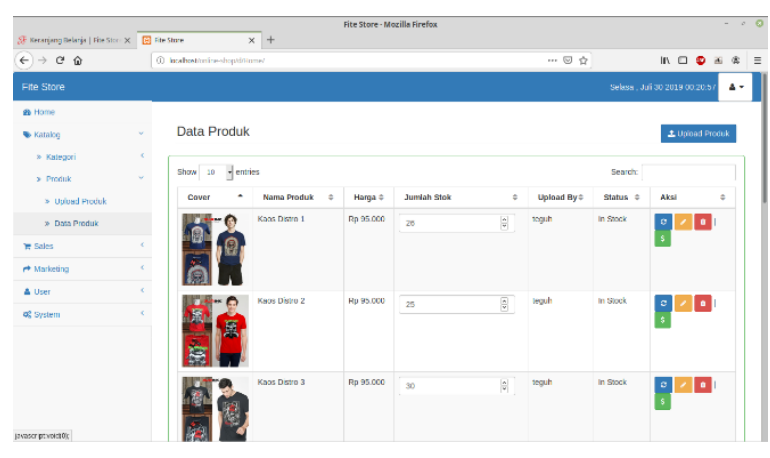

Gambar 4. 9 Halaman Data Produk

e. Halaman Data Order Masuk

Halaman ini digunakan untuk menampilakan data order masuk, data yang tampil pada halaman ini ialah data order dengan setatus sudah dibayar. Berikut tampilan halaman data order masuk:

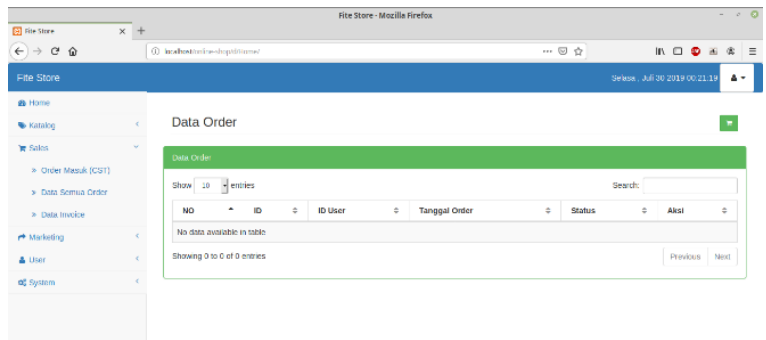

Gambar 4. 10 Halaman Data Order Masuk

f. Halaman Data Semua Order

Halaman ini menampilkan semua data berdasarkan semua status. Berikut tampilan data semua order:

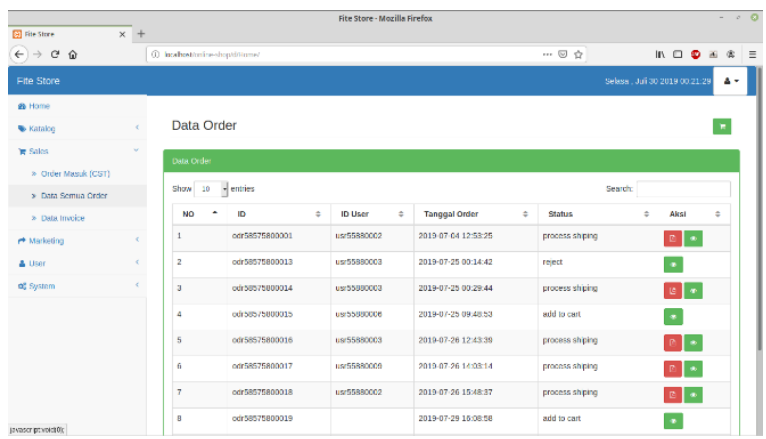

Gambar 4. 11 Halaman Data Semua Order 
g. Halaman Data Diskon

Halaman ini digunakan untuk menampilkan data diskon. Berikut tampilan halaman data diskon:

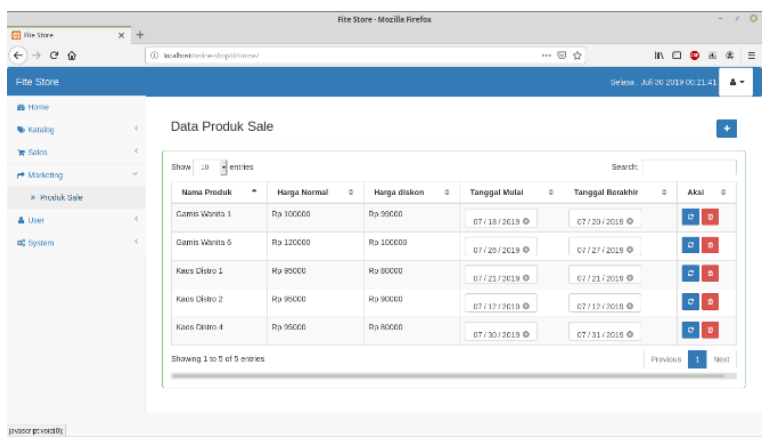

Gambar 4. 12 Halaman Data Diskon

\section{KESIMPULAN}

Berdasarkan analisa dan penelitian dalam penyusunan laporan tugas akhir di SMK Muhammadiyah Cangkringan, serta merancang usulan sistem baru diharapkan dapat meminimalisir permasalahan yang ada. Dari pengamatan yang dilakukukan di SMK Muhammadiyah Cangkringan, masalah utama yang ditemui ialah sistem yang digunakan untuk media praktik jurusan pemasaran merupakan sistem penjualan offline.

Pembuatan aplikasi penjualan barang berbasis website pada jurusan pemasaran di SMK Muhammadiyah Cangkringan dilakukan dengan metode penelitian yang mengacu pada struktur pemodelan waterfall. Harapannya dengan adanya aplikasi penjualan tersebut dapat mempermudah guru dalam mempraktikkan berjualan online, mengingat saat ini ialah eranya internet. Sedangkan berdasarkan hasil pengujian sistem dengan menggunakan metode Black-box Testing, sistem telah berjalan sesuai rencana. Dari pengujian yang telah dilakukan semua proses terindikasi "sukses".

\section{Saran}

Tidak dapat dipungkiri bahwa tidak ada sistem yang sempurna dan tidak memiliki kekurangan, begitu juga dengan aplikasi penjualan barang ini. Oleh karena itu agar aplikasi penjualan barang ini dapat berjalan dengan baik dan sesuai dengan kebutuhan, maka penulis memberikan saran untuk pengembangan lebih lanjut, yaitu:

a. Perlunya pengembangan yang lebih kompleks lagi, semisal didukung dengan fitur lupa password sehingga dapat meminimalisir akun yang tidak aktif.

b. Sistem dikembangkan dengan dukungan API yang lebih baik lagi, semisal dikembangkan dengan API Rajaongkir tipe akun pro sehingga memiliki fitur yang lebih lengkap.

\section{DAFTAR PUSTAKA}

[1] Mikhael, F. dan Heri, K. (2017), Sistem Informasi Penjualan Berbasis Web pada PT Era Makmur Cahaya Damai Bekasi, Bekasi.

[2] Sandi, K. (2014), Pembuatan Sistem Informasi Berbasis Web untuk Memperluas Pangsa Pasar, Pontianak.

[3] Yessy, F. dan Suprianto (2015), Sistem Informasi Penjualan Produk Krupuk Berbasis Web Responsive, Sidoarjo. 